\title{
Efektivitas Kinerja Pegawai UPTD Pasar Betung Kabupaten Banyuasin
}

Femi Asteriniah

Program Studi Ilmu Administrasi Negara, STISIPOL Candradimuka Palembang

E-mail: asteriniah.femi@gmail.com

\begin{abstract}
ABSTRAK
Penelitian ini ini berjudul Efektivitas Kinerja Pegawai UPTD Pasar Betung Kabupaten Banyuasin. Tujuan Penelitian ini adalah untuk mengetahui bagaimana kinerja pegawai UPTD Pasar Betung dalam melaksanakan tugas dan tanggung jawab sebagai pegawai di Pasar Betung Kabupaten Banyuasin. Penelitian ini merupakan penelitian kualitatif, sedangkan pendekatan dalam penelitian ini adalah study kasus yang akan menjelaskan tentang efektivitas Kinerja Pegawai UPTD Pasar Betung Kabupaten Banyuasin. Penelitian ini menggunakan tehnik wawancara dan dokumentasi sebagai alat pengumpul data. Dalam hal ini, informan yang diwawancarai adalah Kepala Dinas Pengelolaan Pasar, Kepala UPTD, Staff Dinas dan UPTD pasar, Pengunjung dan Pedagang pasar. Berdasarkan hasil penelitian dan pembahasan yang telah dilakukan sebelumnya maka disimpulkan mengenai Efektivitas Kinerja UPTD Pasar Betung yang masih mengalami banyak masalah-masalah terutama dari internal pegawai seperti kurangnya kualitas kinerja pegawai terhadap pekerjaan yang dibebankan, penyebab ketidaktepatan waktu pegawai dan kurangnya rasa tanggung jawab pegawai dalam melaksanakan tugas.
\end{abstract}

Kata Kunci: Efektifitas, Kinerja Pegawai, UPTD Pasar Betung.

\begin{abstract}
This research is entitled Effectiveness of Employee Performance at UPTD Pasar Betung, Banyuasin Regency. The purpose of this study was to determine how the performance of UPTD Pasar Betung employees in carrying out their duties and responsibilities as employees at the Betung Market, Banyuasin Regency. This research is a qualitative research, while the approach in this research is a case study which will explain the effectiveness of the Employee Performance of UPTD Pasar Betung, Banyuasin Regency. This study uses interview and documentation techniques as a means of collecting data. In this case, the interviewed informants were the Head of Market Management Service, Head of UPTD, Market Staff and UPTD Market, Visitors and Market Traders. Based on the results of the research and discussion that has been done previously, it is concluded that the Performance Effectiveness of the UPTD Pasar Betung which still experiences many problems, especially from internal employees such as lack of quality of employee performance on the work assigned, causes of employee timeliness and lack of employee responsibility in carrying out Duty.
\end{abstract}

Keywords: Effectiveness, Employee Performance, UPTD Betung Market. 


\section{PENDAHULUAN}

Pasar tradisional pasar yang dibangun dan dikelola pemerintah, pemerintah daerah, swasta, badan usaha milik negara, badan usaha milik daerah termasuk kerjasama dengan swasta dengan tempat usaha berupa toko, los, kios, tenda yang dimiliki dan dikelola oleh pedagang kecil menengah swadaya masyarakat atau koperasi dengan usaha dan proses jual beli barang dagangan melalui tawar menawar (Perpres Nomor.112 Tahun 2007).

Sehubungan dengan eksistensi pasar tradisional yang dimaksudkan ialah keberlangsungan aktivitas pasar termasuk relasi dan jaringannya terhadap pasarpasar lain yang ada disekitarnya. Keberadaan pasar tradisional yang dikelola pemerintah ialah sebagai salah satu penunjang perekonomian daerah, dan juga sebagai penunjang peningkatan Pendapatan Asli (PAD) yang diambil dari penerimaan retribusi pasar. Secara filosofis, retribusi berarti pungutan yang dibebankan kepada masyarakat karena telah mendapatkan imbal balik pelayanan.

Pasar Betung memiliki peran yang besar terhadap masyarakat di Kabupaten Banyuasin dalam memenuhi kebutuhan hidup, khususnya kota Betung yang di jadikan kota perniagaan. Namun pada kenyataannya Kinerja Pegawai UPTD pasar Betung masih mengalami kendala - kendala dilapangan. Untuk menghindari persoalan tersebut perlu dilakukan study mengenai kinerja pegawai UPTD Pasar Betung. Dimana hasil kajian tersebut kemudian diharapkan akan dijadikan sebagai input dalam menjalankan kinerja.

Berdasarkan latar belakan diatas dapat di identifikasi masalah bahwa : 1 . Pegawai UPTD Pasar Betung belum menjalankan tugas pokok dan fungsinya. 2. Sebagai perpanjangan tangan dari Dinas, pegawai UPTD belum sepenuhnya memberikan pelayanan kepada pedagang, baik dari pelayanan administrasi dan penarikan retribusi. Penelitian ini secara fundamental bertujuan untuk masalah secara ilmiah, untuk itu penelitian ini mempunyai tujuan : 1. Menganalisis kinerja Pegawai UPTD Pasar Betung, 2. Memperbaiki kinerja berikutnya.

\section{TINJAUAN PUSTAKA}

\section{Pengertian Efektivitas}

Efektivitas berasal dari kata efektif dan berasal dari bahasa Inggris yaitu effective yang berarti berhasil atau sesuatu yang dilakukan berhasil dengan baik. Efektif juga mengandung pengertian dicapainya tujuan yang telah ditetapkan. Kamus ilmiah populer mendefinisikan efetivitas sebagai ketepatan penggunaan, hasil guna atau menunjang tujuan. Efektivitas merupakan unsur pokok untuk mencapai tujuan atau sasaran yang telah ditentukan di dalam setiap organisasi, kegiatan ataupun program.

Tingkat efektivitas dapat diukur dengan membandingkan antara rencana yang telah ditentukan dengan hasil nyata yang telah diwujudkan. Jika usaha atau hasil pekerjaan dan tindakan yang dilakukan telah tercapai, maka hal itu 
dikatakan efektif. Menurut pendapat David Krech, Ricard S. Cruthfied dan Egerton L. Ballachey dalam bukunya "Individual and Society" yang dikutip Sudarwan Danim dalam bukunya "Motivasi Kepemimpinan dan Efektivitas Kelompok" menyebutkan ukuran efektivitas, sebagai berikut:

1. Jumlah hasil yang dapat dikeluarkan, artinya hasil tersebut berupa kuantitas atau bentuk fisik dari organisasi, program atau kegiatan. Hasil dimaksud dapat dilihat dari perbandingan (ratio) antara masukan (input) dengan keluaran (output).

2. Tingkat kepuasan yang diperoleh, artinya ukuran dalam efektivitas ini dapat kuantitatif (berdasarkan pada jumlah atau banyaknya) dan dapat kualitatif (berdasarkan pada mutu).

3. Produk kreatif, artinya penciptaan hubungannya kondisi yang kondusif dengan dunia kerja, yang nantinya dapat menumbuhkan kreativitas dan kemampuan.

4. Intensitas yang akan dicapai, artinya memiliki ketaatan yang tinggi dalam suatu tingkatan intens sesuatu, dimana adanya rasa saling memiliki dengan kadar yang tinggi. (Danim, 2004:119-120).

\section{Efektivitas Kinerja Pegawai}

Kemampuan organisasi mulai dari menyusun sampai mengorganisasikan sumber daya yang ada untuk mencapai tujuan merupakan ukuran dari efektivitas. Perkembangan dan kemajuan organisasi diberbagai bidang selalu mengedepankan efektivitas kinerja para pegawai yang dapat menggerakkan sekaligus menjalankan roda organisasi. Efektivitas sangat penting peranannya sebagai salah satu cara dalam penyelesaian tugas dan tanggung jawab yang pada dasarnya menunjukkan taraf pencapaian tujuan yang ditentukan. Siswanto mengemukakan bahwa "efektivitas berarti menjalankan pekerjaan yang besar atau kemampuan untuk memulihkan sasaran yang tepat".

Selanjutnya Emerson dalam Handayaningrat mengemukakan bahwa “efektivitas adalah pengukuran dalan arti pencapaian sasaran atau tujuan yang akan ditentukan sebelumnya". Selanjutnya menurut Keban bahwa efektifitas adalah "ketepatan hasil sesuai dengan harapan atau rencana". Menurut Drucker dalam Handoko efektifitas adalah "melakukan pekerjaan yang benar (doing the right things)".

Menurut Kas dalam Sugiyono mengemukakan "Effectiveness is concerned with the accomplishment of explicit or implicit goals. (efektivitas berkenaan dengan derajad pencapaian tujuan baik secara eksplisit maupun implisit)". Beberapa pendapat diatas dapat disimpulkan bahwa, efektivitas adalah melakukan pekerjaan dengan tujuan yang ingin dicapai sesuai dengan hasil yang di harapkan atau yang direncanakan.

Dalam meningkatkan efektivitas kinerja pegawai yang selalu menjadi fokus utama adalah kualitas kerja pegawai hal ini dipandang penting guna meningkatkan kinerja pegawai yang komprehensif. Penggunaan kata kinerja 
sendiri pun kadang-kadang disamaartikan dengan prestasi kerja, efektivitas kerja, hasil kerja, pencapaian tujuan, produktifitas kerja, dan berbagai istilah lainnya. Sekalipun ada persamaan pengertian kinerja dengan berbagai istilah tersebut, akan tetapi terdapat perbedaan pengertian dasarnya maupun prosesnya. Istilah kinerja sendiri merupakan tujuan dari prestasi kerja atau prestasi sesungguhnya yang dicapai seseorang. Menurut Wibowo "kinerja adalah merupakan implementasi dari rencana yang telah disusun".

Menurut Fahmi "kinerja adalah hasil yang diperoleh oleh suatu organisasi baik organisasi tersebut bersifat profit oriented dan non oriented yang dihasilkan selama satu periode waktu". Menurut Simanjuntak "kinerja adalah tingkat pencapaian hasil atas pelaksanaan tugas tertentu". Beberapa pendapat diatas dapat disimpulkan bahwa kinerja merupakan hasil yang diperoleh suatu organisasi dari rencana yang telah disusun. Kinerja pegawai pada dasarnya merupakan perilaku nyata yang dihasilkan setiap orang sebagai prestasi kerja yang dihasilkan oleh pegawai sesuai perannya dalam organisasi. Untuk mendapatkan kinerja yang baik dari seorang pegawai pada sebuah organisasi harus dapat memberikan sarana dan pra sarana sebagai penunjang dalam penyelesaian pekerjaan. Menurut Mangkunegara Kinerja pegawai "Adalah hasil kerja secara kualitas dan kuantitas yang dicapai oleh seorang pegawai dalam melaksanakan tugasnya sesuai dengan tanggung jawab yang diberikan kepadanya".
Menurut Sinambela mendefinisikan Kinerja pegawai: "Adalah pelaksanaan suatu pekerjaan dan penyempurnaan pekerjaan tersebut sesuai dengan tanggungjawabnya sehingga dapat mencapai hasil sesuai dengan yang diharapkan"

$$
\text { Dari uraian diatas dapat }
$$
disimpulkan bahwa efektivitas kinerja pegawai merupakan hasil kerja yang telah direncanakan atau ditetapkan sebelumnya untuk dicapai seorang pegawai dalam suatu organisasi terkait pelaksanaan kegiatan dengan tujuan untuk mewujudkan sasaran yang telah ditetapkan sebelumnya oleh suatu organisasi.

\section{Kerangka Pemikiran}

Suatu organisasi dalam mencapai proses kerja yang lebih baik dalam menyelesaikan tugas merupakan bentuk dari efektivitas. Efektivitas kinerja pegawai adalah hasil kerja pegawai dalam melakukan atau melaksanakan tugas atau pekerjaan sesuai dengan tanggungjawab dan tujuan yang ingin dicapai sesuai dengan yang di harapkan atau direncanakan secara kualitas dan kuantitas.

Efektifitas kinerja pegawai dalam penelitian ini diukur berdasarkan pendapat Bernardian dan Rusell dalam Gomes yaitu Kuantitas pekerjaan, Kualitas pekerjaan, Pengetahuan terhadap pekerjaaan, Kreativitas, Kerjasama, Keteguhan dalam bekerja, Inisiatif dan Kualitas pribadi. Akan tetapi yang menjadi fokus utama dalam penelitian ini yaitu Kuantitas pekerjaan, Kualitas pekerjaan, Kerjasama, Pengetahuan 
tentang kerja, Keteguhan dalam bekerja, Inisiatif.

Terciptanya efektivitas kinerja pegawai yang baik diharapkan mampu menjamin kelancaran terhadap kinerja pegawai secara baik dan tepat khususnya aparatur pemerintah dalam penelitian ini yaitu pegawai badan perencanaan pembangunan daerah kota makassar agar lebih profesional dan berkualitas. Dari penjelasan tersebut dapat disimpulkan kerangka berpikir dalam penelitian ini:

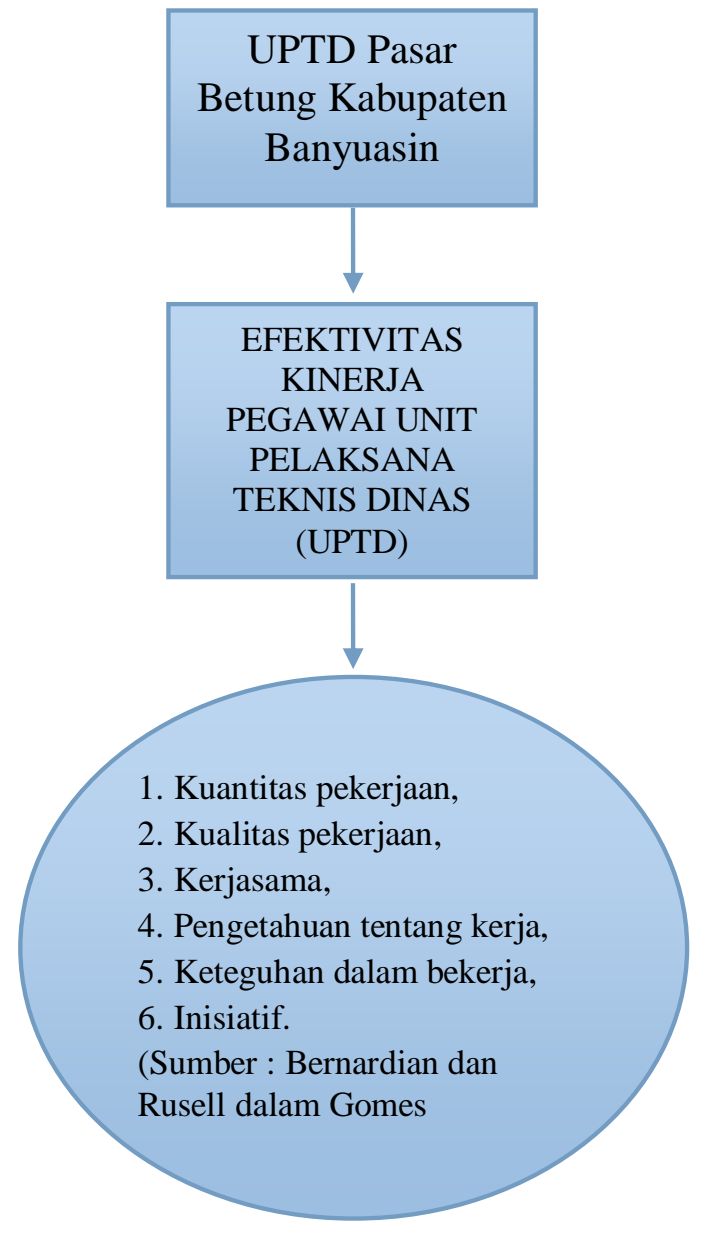

\section{METODE PENELITIAN}

Penelitian dilaksanakan di UPTD Pasar Betung Kabupaten Banyuasin relevan dengan permaslahan penelitian ini sebagai tempat dalam mencari dan mengumpulkan data yang berguna dalam penelitian.

Rancangan penelitian yang digunakan dalam penelitian ini adalah penelitian yang bersifat kualitatif. . Kegiatan yang diawali dengan melihat kondisi kantor UPTD Pasar Betung yang kemudian dijadikan sebagai dasar untuk menjelaskan adanya keadaan terkini dari kinerja pegawai dalam melayani pedagang atau masyarakat. Setelah melakukan observasi kemudian dilengkapi dengan data, dokumendokumen atau sumber sumber lain yang terkait dengan kinerja UPTD Pasar Betung.

Informan yang digunakan dalam penelitian ini dapat dilihat pada Tabel 1.

Tabel 1. Informan

\begin{tabular}{cll}
\hline NO & \multicolumn{1}{c}{ Informan } & Jumlah \\
\hline 1. & Kepala Dinas Pengelolaan & 1 orang \\
& Pasar & \\
2. & Kepala UPTD Pasar & 1 orang \\
3. & Kabid Pendapatan & 1 orang \\
4. & Kasubag TU Pasar & 1 orang \\
5. & Masyarakat & 1 orang \\
\hline \multicolumn{2}{c}{ Jumlah } & 5 orang \\
\hline
\end{tabular}

Sumber: diolah oleh Penulis

Berdasarkan berkaitan dengan penelitian ini maka variabel yang diteliti merupakan variabel mandiri atau tunggal yaitu "Efektivitas Kinerja Pegawai UPTD Pasar Betung Kabupaten Banyuasin.

Data penelitian yang dikumpulkan melalui tiga teknik yaitu: 
1. Observasi artinya penulis turun langsung kelokasi penlitian dan meneliti dan mengamati serta mencatat seluruh masalah yang ada atau terjadi.

2. Wawancara artinya penulis mengadakan tanya jawab langsung kepada key informan

3. Dokumentasi adalah data yang berupa kearsipan.

Dalam menganalisis data suatu permasalahan dari penelitian ini, Penulis mengunakan metode analisis deskriptif kualitatif yaitu metode yang menggunakan kalimat-kalimat penjelasan guna menyampaikan informasi yang diinginkan. Dalam kaitannya dengan judul penelitian ini Penulis akan menganalisis dan mengkaji seluruh data yang diperoleh dari semua sumber data baik data primer maupun data skunder terkait dengan Efektivitas Kinerja Pegawai UPTD Pasar Betung Kabuapten Banyuasin sehingga Penulis dapat memperoleh gambaran dan dapat menyimpulkan hasil identifikasi dan rumusan masalah dari penelitian tersebut.

\section{HASIL PENELITIAN}

Sesuai dengan Keputusan Bupati Banyuasin, UPTD Pasar Betung merupakan satuan unit kerja yang berada langsung dilapangan yang berhadapan langsung dengan pedagang. Hal ini juga tidak terlepas dari peran Kepala UPTD yang memimpin langsung UPTD tersebut. Sejak tahun 2015 target pendapatan Dinas Pengelolaan Pasar tidak mencapai target yang ditentukan, hal ini disebabkan setoran dari pendapatan UPTD pasar menurun.
Dilihat dari rekapitulasi penerimaan retribusi pelayanan pasar Dinas Pengelolaan Pasar Kabupaten Banyuasin.

UPTD Pasar Betung merupakan perpanjangan tangan sekaligus pelaksana kebijakan - kebijakan kepala Dinas dalam memberikan pelayanan dalam tugas dan fungsinya dilapangan. Sejak berdirinya pasar UPTD dibentuk untuk melaksanakan tugas tugas dilapangan. Pada penelitian ini, variabel yang diteliti adalah Efektivitas Kinerja Pegawai UPTD Pasar Betung Kabupaten Banyuasin.

\section{Kuantitas Pekerjaan}

Dari jumlah aktivitas yang dihasilkan oleh UPTD masih banyak kekurangan - kekurangan yang kami dapat dari UPTD seperti setoran retribusi, yang berdasarkan hasil rekapitulasi penerimaan retribusi pelayanan pasar Dinas Pengeloaan Pasar Kab. Banyuasin Tahun Anggaran 2016, dalam tiap bulannya masih terdapat setoran yang tidak target, kami selaku pegawai dinas sangat mengeluhkan hal ini, apakah memang kinerja dari pegawai UPTD yang lalai atau memang pedagang yang tidak mau membayar retribusi yang telah ditetapkan untuk pedagang.

Sebagai pemegang kebijakan dari dinas, seharusnya KUPTD menjalankan tugas berdasarkan bidangnya, dalam penyetoran retribusi yang telah ditetapkan oleh Dinas Pengelolaan Pasar Kabupaten Banyuasin, dari jumlah karcis yang diberikan, seharusnya jumlah hasil dari setoran sama dengan karcis yang dikeluarkan oleh Dinas Pengelolaan Pasar. 


\section{Kualitas Pekerjaan}

Kualitas Pekerjaan dicapai berdasarkan sejauh mana mutu seorang pegawai dalam melaksanakan tugastugasnya. Kualitas pekerjaan bisa dilihat melalui hasil pekerjaan yang dilakukan, dan usaha-usaha apa saja yang dilakukan untuk meningkatkan kualitas pekerjaan.

\section{Dalam kemampuan bekerja} dilapangan pegawai UPTD Pasar Betung sudah berusaha semaksimal mungkin menjalankan pekerjaannya untuk melayani pedagang dan masyarakat, demi tujuan yang diinginkan. Apabila pegawai tidak mempunyai kemampuan bagaimana organisasi akan tercapai tujuannya apabila kinerja pegawai tidak maksimal dan tidak sesuai dengan kemampuannya.

\section{Kerjasama}

Dalam sebuah organisasi dibutuhkan kerja sama agar tercipta rasa kekeluargaan dan saling membantu untuk mencapai tujuan yang telah ditetapkan. Tujuan oganisasi yang akan dicapai secara efektif apabila ada kerja sama antar anggota organisas tersebut.

Dalam hal kerja sama Kepala UPTD Pasar mengemukakan bahwa "Kami harus bekerja sama kalau tidak bekerja sama pincang, karena kita saling keterkaitan, kalau kemajuan atau kinerja SKPD diukurnya dari situ kalau tidak bisa bekerja sama tentu SKPD-nya pincang.

Dari hasil wawancara tersebut dapat disimpulkan bahwa, kerja sama pegawai sudah berjalan baik dilihat dari kekompakan, rasa kekeluargaan, dan tolong menolong dalam bekerja. Hasil ini sesuai dengan dengan hasil obervasi ketika ada pegawai yang berhalangan hadir, maka pegawai lainnya akan membantu mengerjakan tugas pegawai tersebut selama tidak bertentangan dengan aturan yang berlaku

\section{Pengetahuan Tentang Kerja}

Pengetahuan dalam terhadap pekerjaan merupakan sejauh mana pengetahuan pegawai mengenai pekerjaannya, serta sejauh mana pegawai mengetahui antara pekerjaan yang dilakukan dengan tupoksi yang telah ditetapkan. Tujuan organisasi akan tercapai dengan efektif jika pegawai mempunyai pengetahuan terhadap pekerjaannya.

Hasil ini relevan dengan hasil observasi dengan pegawai membuktikan bahwa pegawai di pegawai UPTD Pasar Betung sudah memahami tugas dan kewajiban dalam bekerja sehingga otomatis pegawai akan memiliki pengetahuan tehadap pekerjaannya yang sudah menjadi rutinitas.

\section{Keteguhan Dalam Bekerja}

Seorang pegawai sebaiknya memiliki rasa yang kuat dalam bekerja sehingga dapat menghasilkan pekerjaan yang berkualitas. Kehadiran dalam bekerja merupakan kesadaran untuk dapat dipercaya, dalam hal menyelesaikan pekerjaan sebaik-baiknya dan tepat waktu yang wajib terlaksana demi pencapaian tujuan organisasi yang efektif.

Berdasarkan hasil wawancara dapat disimpulkan bahwa pegawai sudah memenuhi kehadiran kerja dan penyelesaian pekerjaan dengan tepat waktu dengan sebaik-baiknya dan sudah cukup baik walaupun dalam hal 
kehadiran masih ada pegawai yang datang terlambat, hasil ini sesuai dengan hasil observasi namun terus diadakan evaluasi dan pembinaan untuk meningkatkan kedisiplinan pegawai yang berdampak pada optimalisasi pekerjaan dan efektivitas kinerja pegawai.

\section{Inisiatif}

Inisiatif merupakan kemampuan melakukan atau 92 melaksanakan sesuatu tanpa harus diberitahu atau diperintah. Pegawai yang baik adalah pegawai yang ketika bekerja dia mendapat kendala atau masalah, dia akan berusaha mencari solusi untuk keluar dari masalah tersebut tanpa menunggu bantuan untuk masalah tersebut.

Dari hasil wawancara tersebut dapat disimpulkan bahwa, pegawai pegawai UPTD Pasar Betung memiliki inisiatif dalam bekerja sesuai dengan tupoksi dan tanggung jawabnya tanpa harus menunggu perintah untuk bekerja, Hasil ini relevan dengan hasil observasi bahwa dengan adanya inisiatif tersebut penyelesaian kerja pegawai akan semakin cepat dan tujuan organisasi dapat tercapai.

\section{PEMBAHASAN}

Kejelasan informan tersebut merupakan suatu ukuran tentang cara kepegawaian dalam menjalankan tugas dan fungsi sebegaiamana yang dimaksud penyusunan kebijakan teknis dibidang kepegawaian, dalam pelaksanaan urusan pembuatan izin sewa, penarikan retribusi karcis, penarikan retribusi sewa los kios, pembukuan keuangan setoran bank, sesuai dengan fungsi dan tugas pokok masing - masing yang sudah ditetapkan oleh pemerintah. Sesuai dengan peraturan Bupati Nomor 668 Tahun 2011 Tentang Pembentukan Organisasi dan Tata Kerja Unit Pelaksana Tekniis Dinas (UPTD) pengelolaan Pasar daalm Jajaran DInas Pengelolaan Pasar Kabupaten Banyuasin.

Secara garis besar pegawai dalam sebuah instusi atau unit daalm hal ini UPTD pasar mempunyai tugas membantu kepala Dinas menjalankan tugasnya sesuai dengan peraturan yang sudah ditetapkan oleh peraturan Bupati. Sistem yang dapat diselami untuk menilai mengenai kualitas pekerjaan pegawai UPTD pasar Betung Kabupaten Banyuasin, dlihat dari pekerjaan secara rill kedisplinan pegawai daa kehadiran dan menjalankan tugasnya secara penggunaan waktu dalam menyelesaikan pekerjaan secara efektif dan efisien.

Berdasarkan wawancara diatas telah diketahui kualitas kinerja pegawai UPTD paasr Betung melalui beberapa waktu yang dibutuhkan pegawai untuk dapat menyelesaikan pekerjaan secara efisien. Hal yang juga sangat penting dapat melihat kualitas pegawai adalah kedisiplinan kehadiran pegawai. Sesuai dengan paparan mengenai wawancara kedisiplinan yang dinilai melalui absensi. Maka data yang diperoleh atasan untuk menilai pegawainya adalah melalui data data absensi. Jika para pegawai melanggar maka dampak sanksinya dapat berupa lisan maupun tertulis. Dalam hal ini kedisiplinan merupakan bagian penting untuk melihat kualitas pegawai melalui data - data absensi yang ada yang dapat melihat data - data absensi yang ada yang dapat melihat data - data 
kehadiran, keterlambatan pegawai dan ketika pegawai keluar kantor.

Kedisiplinan ini sangat erat kaitannya untuk mengetahui kinerja pegawai sebagai faktor individu yang sangat penting karena juga berpengaruh terhadap integritas individu atau pegawai kepada institusi atau UPTD. Dalam menyelesaikan pekerjaan yaitu melayaani pedagang dalam membuat izin sewa los kios kontrak, penarikan retribusi, dan pembukuan retribusi yang harus diselesaikan sesuai dengan apa yang diperintahkan oleh atasan. Hal ini sejalan dengan gagasan yang dipaparka oleh Mangkunegara (2006:16) yang memapaparkan bahwa bahwa secara psikologis individu yang normal ada;ah individu yang memiliki integritas yang tinggi maka individumampu mengelola dan memberdayakan potensi dirinya secara optimal. Individu disini dapat dilihat pada pegawai-pegawai UPTD pasar Betung Kabupaten Banyuasin yang memang saat ini telah memiliki kedisiplinan yang tinggi dan dapat dilihat dari hasil wawancara diatas. Pegawai UPTD juga telah memiliki pengertiam mengenai kedisiplinan.

Kedisiplinan serta integritas yang tinggi tentu akan menghasilkan kegiatan dan aktivitas, yang optimal sehingga akan mendapatkan pengukuran kinerja setiap pegawai. Pengukuran kinerja bukan hanya dilihat dari tingkat kedisiplinan dalam menjalankan tugas maupun kedisiplinan dalam kehadiran tetapi dapat juga dapat dilihat mengenai efektifitas dan efisiensi waktu yang diperlukan perlukan pegawai untuk menyelesaikan pekerjaan.

\section{KESIMPULAN DAN SARAN}

Kinerja pada dasarnya merupakan hasil kerja baik secara kualitas dan kuantitas yang dicapai seorang pegawai dalam melaksanakan tugasnya sesuai tanggung jawab yang dibebankan kepadanya dalam hal ini, pegawai bisa belajar seberapa besar kinerja mereka melalui sarana informasi seperti komentar baik dari mitra kerja namun demikian penilaian kinerja yang mengacu kepada suatu sistem formal dan terukur untuk menukar, menilai dan mempengaruhi sifat-sifat yang berkaitan dengan pekerjaan perilaku dan hasil ketidakdisiplinan.

UPTD pasar Betung sebagai pelaksana dalam pelayanan kepada pedagang di lokasi pasar, mempunyai tugas dan fungsi yang harus dijalankan oleh pegawai agar dapat tercapainya tujuan yang diharapkan. Kedisiplinan yang harus ditaati oleh pegawai UPTD pasar Betung merupakan suatu faktor utama yang harus dipatuhi untuk menjalankan pekerjaan di UPTD pasar Betung, pada dasarnya pegawai UPTD pasar Betung sudah cukup baik dan menjalankan sesuai dengan aturan yang telah diterapkan oleh pemerintah, dalam melayani pedagang dan masyarakat yang berkunjung di area Pasar Betung.

Kinerja merupakan tolok ukur keberhasilan dari suatu organisasi dimana seorang pegawai harus mampu menjalankan peran dan fungsinya dalam melaksanakan tugasnya. Berdasarkan wawancara yang dilakukan telah diketahui bagaimana kualitas kinerja pegawai UPTD Pasar Betung Kabupaten Banyuasin melalui beberapa waktu yang 
dibutuhkan untuk dapat menyelesaikan pekerjaan secara efisien. Hal ini yang juga sangat penting dapat melihat kualitas pegawai adalah kedisiplinan kehadiran pegawai dan rasa tanggung jawab atas pekerjaan yang dibebankan kepada pegawai dari atasan atau pimpinan.

Sesuai dengan paparan yang mengenai wawancara kedisiplinan yang dinilai melalui absensi. Baik absensi manual maupun absensi sidik jari yang diterapkan agar kehadiran pegawai sesuai dengan kehadiran yang memang benar mereka hadir paad saat jam kerja. Jika para pegawai melanggar maka dapat sanksi yang berupa tulisan atau lisan. Dalam hal ini kedisiplinan merupakan bagian penting untuk melihat kualitas pegawai melalui data-data absensi yang ada, dapat melihat kehadiran, keterlambaatn pegawai dan ketika keluar kantor.

\section{DAFTAR PUSTAKA}

[1] Peraturan Presiden Nomor. 112 Tahun 2007

[2] Peraturan Bupati Nomor. 668 Tahun 2011, Tentang Pembentukan UPTD
[3] Simamora, Hendry, 2004. Menejemen Sumber Daya Manusia, Edisi 3 Cetakan 1 bagian Penerbitan STIE YKPN : Yogyakarta

[4] Hasibuan SP. Malayu, 2007. Menejemen Sumber Daya Manusia, Edisi revisi, Bumi Aksara : Jakarta

[5] Mangkunegara, Anwar Prabu. 2004. Evluasi Kinerja Sumber daya Manusia, Penerbit :PT Rafika Aditama : Bandung

[6] Mangkunegara, A.A Anwar Prabu, 2006. Evaluasi Kinerja Sumber Daya Manusia, PT Rafika Aditama : Bandung

Manulang, M, 1981. Menejemen Personalia, Ghalia Indonesia: Jakarta

[7] Syaidan, Gouzali, 2000, Menejemen Sumber Daya Manuasia (Human ResourcesManagement), Djambatan: Jakarta

[8] Sedarmayanti. 2007. Menejemen Sumber Daya Manusia, Penerbit CV Pustaka Setia: Bandung

[9] Simamora, Hendry. 2001. Menejemen Sumbe Daya Manusia, Penerbit STIE YKPN,Yogyakarta

[10]Suyanto, Bagong. 2005. Metode Penelitian Sosial: Berbagai Alternatif Pendekatan. Jakarta: Prenada Media 